\title{
The impact of group education on students' grit and educational self-efficacy based on Snyder's hope theory
}

\author{
Mohammad Narimani ${ }^{1}$, Saeede Hedayat ${ }^{2}$ \\ 1-Professor, Department of Psychology, University of Mohaghegh Ardabili, Ardebil, Iran. \\ 2-PhD Student, Department of Psychology, University of Mohaghegh Ardabili, Ardebil, Iran (Corresponding \\ Author). $\quad$ E-mail: hedayat@uma.ac.ir
}

Received: 07/04/2020 Accepted: 09/06/2020

\begin{abstract}
Introduction: Hope is one of the most important points in people's lives, a key motivating factor in the growth and development of human capital in societies and is directly related to students' academic achievement and mental health.

Aim: The aim of this study was to investigate the impact of group education on grit and educational self-efficacy of students based on Snyder's hope theory.

Method: The experimental design was a pre-test-post-test with control group. The statistical population of this study included all primary school students studying in the public schools in district 3 of Kermanshah, Iran during the academic year of 2019-2020. 30 sixth-year elementary school male students were selected as a statistical sample using random cluster sampling and were placed in two experimental (15 subjects) and control (15 subjects) groups. The subjects in the experimental group were trained for 8 sessions based on Snyder's hope theory, but the control group did not receive any intervention. Morgan \& Jinks' educational self-efficacy scale and Duckworth's grit scale were used to collect data. The information obtained from the questionnaires was analyzed using covariance statistical method.
\end{abstract}

Results: The findings showed that group education based on Snyder's hope theory had a significant effect on grit $(\mathrm{F}=0.43)$ and educational self-efficacy $(\mathrm{F}=0.56)$ of the experimental group $(\mathrm{P}<0.05)$.

Conclusion: Based on these findings, it can be said that group hope education is effective in increasing students' grit and educational self-efficacy, and after hope training, students' academic success can be expected.

Keywords: Group education based on Snyder's hope theory, Grit, Educational self-efficacy

How to cite this article : Narimani M, Hedayat S. The impact of group education on students' grit and educational self-efficacy based on Snyder's hope theory. Shenakht Journal of Psychology and Psychiatry. 2020; 7 (3): 112-123 .URL: http://shenakht.muk.ac.ir/article-1-869-en.pdf

Copyright ( 2018 the Author (s). Published by Kurdistan University of Medical Sciences. This is an open access article distributed under the terms of the Creative Commons Attribution-Non Commercial License 4.0 (CCBY-NC), where it is permissible to download, share, remix, transform, and buildup the work provided it is properly cited. The work cannot be used commercially without permission from the journal. 


\title{
اثربخشى آموزش كروهى مبتنى بر نظريه اميد اسنايدر بر ميزان ثبات قدم و خودكار آمدى تحصيلى دانش آموزان
}

\begin{abstract}
محمد نريمانى'، سعيده هدايت
1.استاد ممتاز، گروه روانشناسى، دانشكاه محقق اردبيلى، اردبيل، ايران.

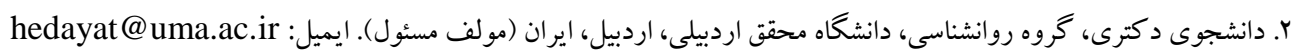

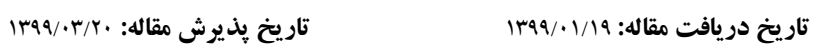

جكيده

مقدمه: اميد يكى از موضوعات مهم در ارتباط با زندگى افراد و عامل كليدى انگيزه بخش در رشد و ييشرفت سرمايههاى انسانى آن جامعه است و رابطه مستقيمى با بيشرفت تحصيلى و سلامت روانى دانش آموزان دور دارد. هدف: يزوهش حاضر با هدف بررسى اثربخشى آموزش گروهى مبتنى بر نظريه اميد اسنايدر بر ميزان ثبات قدم و خودكار آمدى تحصيلى دانش آموزان انجام شد.

روش: يزوهش حاضر يكك مطالعه شبه آزمايشى از نوع بيش آزمون- پيس آزمون با خروه كنترل بود. جامعه آمارى اين يزوهش، شامل

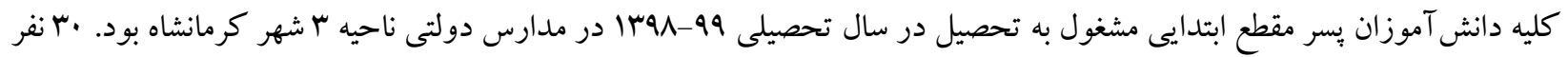

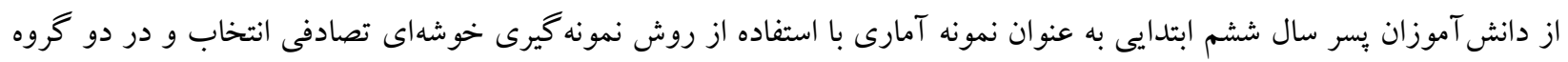

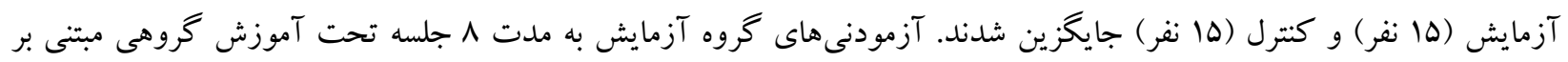

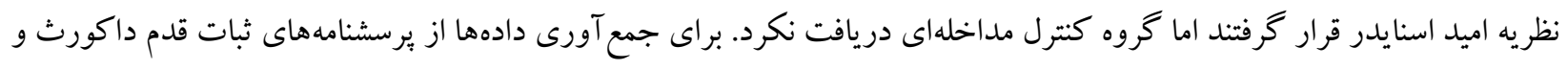

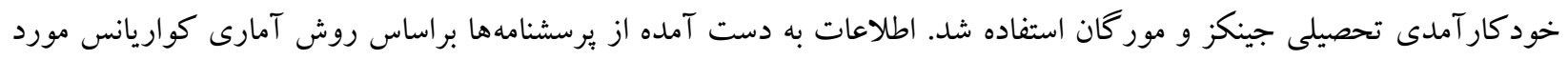
تجزيه و تحليل قرار گرفت.

يافتها: يافتها نشان داد كه آموزش گروهى مبتنى بر نظريه اميد اسنايدر بر ميزان ثبات قدم (F=/F/F) (F=./D9) نتيجه كيرى: بر اساس اين يافتها مىتوان گفت كه آموزش اميد به روش گروهى بر افزايش ميزان ثبات قدم و خودكارآمدى تحصيلى دانش آموزان اثر گذار است و به دنبال آموزش اميد مى توان موفقيت تحصيلى دانش آموزان را انتظار داشت. كليدوازهها: آموزش گروهى مبتنى بر نظريه اميد اسنايدر، ثبات قدم، خود كار آمدى تحصيلى 


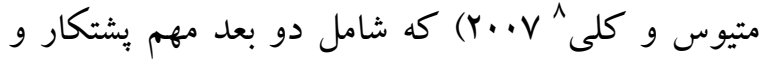

مقدمه

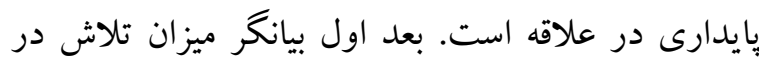
جهت اهداف تعيينشده و بعد دوم آن نشاندهنده تمركز و تعهد به مجموعهاى از اهداف مهم است (بركى'، 1)، (Y.11، به طورى كه سطح اشتياق و علاقه براى رسيدن به هدفهاى از بيش تعيينشده را افزايش مىدهد و موجب تعهد و يشتكار بالا مىشود (حسينى، ذوقى بايدار

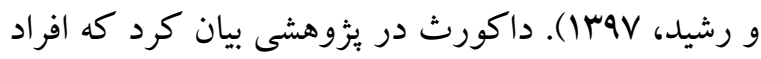
باثبات قدم بالاتر موفقيتهاى تحصيلى بهترى را كسب مى كنند و اين خصيصه نسبت به هوش بيشبينى كننده قوىترى براى موفقيت است (داكورث و همكاران،

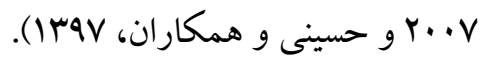

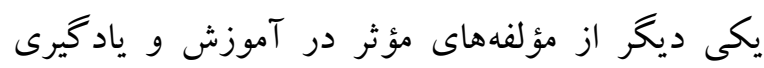

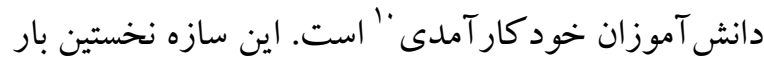

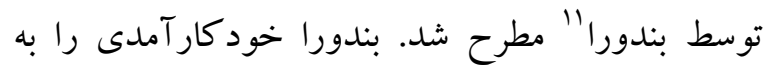
عنوان قدرت ارزيابى توانايىهاى خود تعريف كرده است

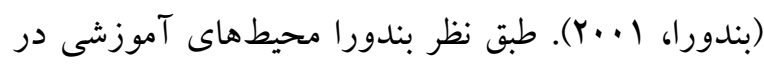
رشد و شكل گيرى خود كارآمدى دانش آموزان مناسب

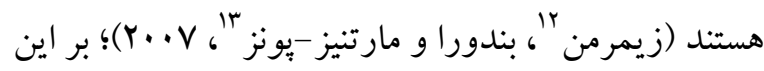

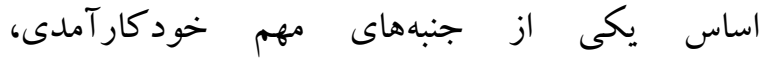

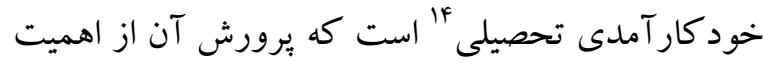
ويزهاى برخوردار است. خودكارآمدى تحصيلى باور دانشآموز درباره توانايىها و استعدادهاى خود براى فهميدن يا انجام دادن تكاليف درسى و رسيدن به اهداف در يكك زمينه تحصيلى مشخص است (آلتونسوى سيمن،

8 - Peterson, Matthews \& Kelly

9 - Berk

${ }^{10}$ - Self-efficacy

${ }^{11}$ - Bandura

${ }^{12}$ - Zimmerman

13- Martinz-Ponz

${ }^{14}$ - Academic self-efficacy

\footnotetext{
1- Attention

${ }^{2}$ - Mindset

3 - Grit

${ }^{4}$ - Farrington, Roderick, Allensworth, Nagaoka, Keyes, Johnson \& Beechum

5 - Cross \& Arizona

6. Ivcevic \& Brackett

7- Duckworth
}

تحقيقات در زمينه آموزش و ياد گيرى نشان مىدهد كه ينج عنصر شناختى و غيرشناختى در بيشبينى موفقيت تحصيلى نقش دارند كه عبارتاند از: توجه'، جارجيوب ذهنى '، ثبات قدم"' راهكارهاى ياد گيرى و مهارتهاى اجتماعى (فارينكتون، رودريك،، آلنس وورث، ناكو كا،

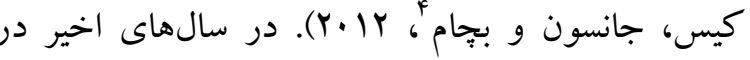
ادراكك تو انايىهاى غيرشناختى كه ياد كيرى دانش آموزان را ارتقا مىبخشد بيشرفتهاى جشمخيرى ديده مىشود. مطالعات نشان دادهاند كه تو انايىهاى غيرشناختى از جمله ثباتقدم با عدم وابستخى به توانيى و مهارتهاى

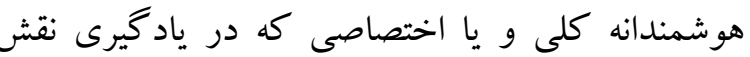
دارند؛ بيشتر از هوش براى موفقيت داراى اهميت هستند

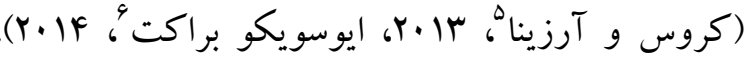
نظريه ثبات قدم بر اساس مطالعات داكورث \در سال

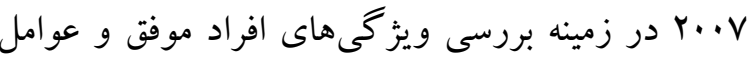
مؤثر بر موفقيت آنها ارائه شد (داكورث، يترسون، 
افزايش تفكر عامل يا كارگزار مى گردد و تفكر عامل نوعى انرزى و توان ذهنى است (به نقل از يعقوبى، فروتنبقا و محققى، سهو|). بررسىهاى متعددى نشان داده است كه سطوح بالاى اميد با عملكرد بالاى تحصيلى در دوره ابتدايى، راهنمايى، دبيرستان و دانشگاه همراه است و يكك بيشبينى كننده معتبر براى موفقيتهاى

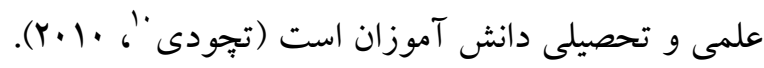
تحقيقات انجام گرفته نشان مىدهد بين دو سازه اميدوارى

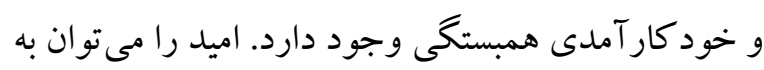
عنوان يكك مفهوم كلى تعريف كرد كه بر اساس خود كار آمدى شكل كرفته و باورى است كه غلبه بر موانع موجود در رسيدن به هدف را شامل مىشود (ميكائيلى منبع، فتحى، شهودى و زندى، سوسا). قدميور

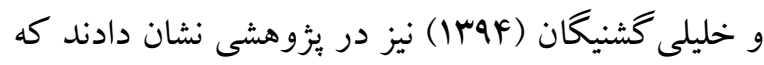
سازه اميد با خود كار آمدى تحصيلى دانش آموزان مرتبط است و مىتواند به طور مثبت موفقيت دانش آموزان را يبشبينى كند. همجنين در اين راستا اريكسون-دو كتر و

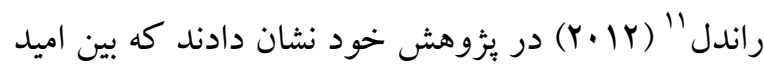
و ثبات قدم دانش آموزان رابطه معنادارى وجود دارد بهطورى كه با افزايش اميد در فرد، انخيزه در گير شدن در

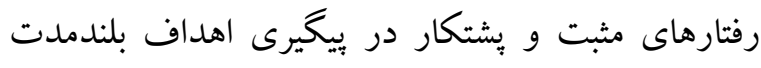

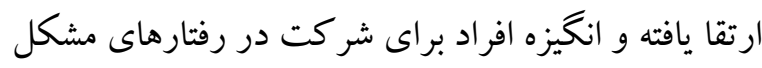
آفرين كاهش مىيابد. از بررسى مطالعات و يثزوهشهاى اخير جنين استباط مى شود كه اميد در دانشآموزان مىتواند كوششها و يبشرفت هاى آنها را تحت تأثير قرار دهد. بررسى و مرور ييشينه بيزوهش بيانكر اين است كه اكثر مطالعات بيشين در خصوص متغيرهاى يثوهش از نوع همبستخى بوده و

${ }^{10}$ - Tschudy

${ }^{11}$ - Erickson- Dockter \& Randal
اكسى، اتيك و كو كمن'، · · (Y). كاليون، بلوندين، ياو،

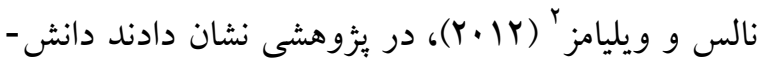
آموزانى كه داراى خودكار آمدى تحصيلى بالا هستند، توانيى بهترى در مديريت يادگيرى خود دارند و در مقابل فشارهاى اجتماعى كه ممكن است موجب عدم موفقيت آنها شود، با اطمينان به خود و توانايىهايشان

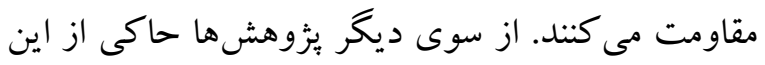
است كه كمبود يا فقدان خود كار آمدى تحصيلى، اغلب انكيزه دانش آموزان را تضعيف كرده و منشأ بسيارى از مشكلات از قبيل افت تحصيلى و مشكلات روحى و

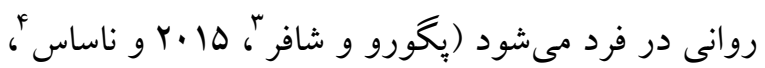
ناساس (Y) (Y) (Y) ئزوهشخران بر اين باورند كه اميده يكى از ضروريات مهم براى مقابله با مشكلات و سلامت روان انسان است و به نظر مىرسد اميدوارى در دانشآموزان نيز يكى از مؤلفهاى اساسى براى رشد تحصيلى و يادگيرى آنان -

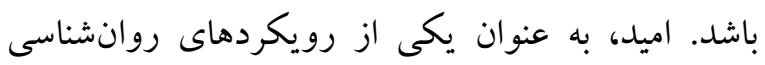
مثبت گرا" در دهه اخير مورد توجه روانشناسان قرار كرفته است. بر اساس نظريه اميد اسنايدر، اميد به عنوان

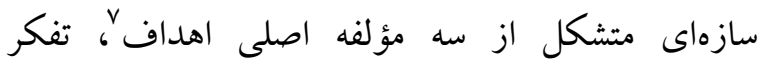
كذر گاهُ و تفكر عامل (كارگزار)" مفهومسازى شده است. طبق اين مفهوم اميد فر آيندى است كه طى آن افراد

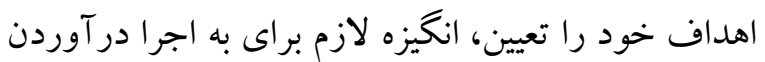
اين راهكارها را ايجاد و در طول مسير حفظ مى كنند

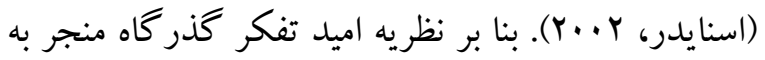

\footnotetext{
1- Altunsoy, Çimen, Ekici, Atik, \& Gökmen

${ }^{2}$ - Galyon, Blondin, Yaw, Nalls, Williams

3 - Peguero, \& Shaffer

${ }^{4}$ - Nasa

5 - Hope

${ }^{6}$ - Positive psychology

7. Goals

8. Pathway thinking

9 - Agency thinking
} 
تحصيلى از آزمون هوش ريون و دريافت نمرههاى كلاسى آنان از مدير مدرسه استفاده شد و بر اساس نمرههاى كلاسى و هوش، لها نفر در گروه آزمايش و ها نفر در گروه كنترل به صورت تصادفى جايخزين شدند. ملاككهاى ورود به يُزوهش عبارت بودند از: داشتن تمايل براى مشاركت در يُزوهش و مبتلا نبودن به اختلالات روانشناختى. ملاكك خروج از ئزوهش نيز غيبت بيش از Y جلسه در جلسات آموزشى بود.

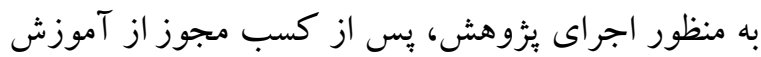

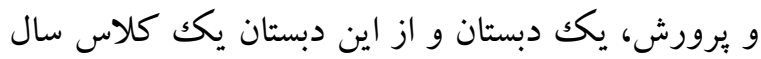
ششم به صورت تصادفى انتخاب شد. يس از انتخاب تصادفى دو گروه آزمايش و كنترل، در شرايط يكسان و قبل از هر گونه مداخله، با همكارى مشاور مدرسه درو درو مورد نحوه ياسخگگ بِيى به يرسشنامهها راهنمايىهاى لازم

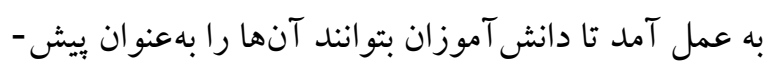
آزمون تكميل نمايند. گروه آزمايش بعد از اجراى بيش آزمون در جلسات گروهى مبتنى بر نظريه اميد اسنايدر شركت كردند. در طول مداخله دانش آموزان كروه كنترل هيج گونه آموزشى دريافت نكردند. هدف آموزش مبتنى بر نظريه اميد اسنايدر بهصورت

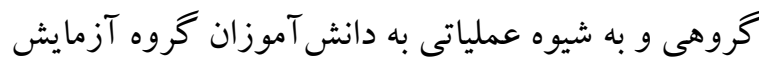

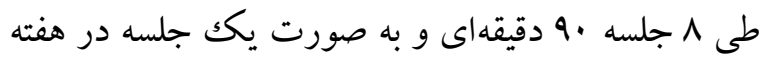
با حضور در مدرسه ارائه شد. در اين راستا از كتاب فنون

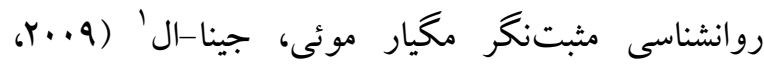

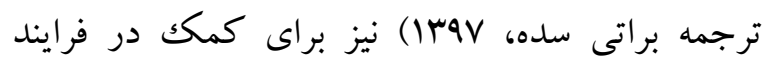

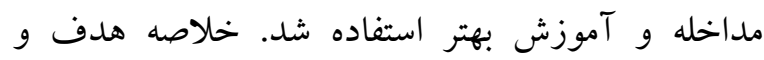
محتواى جلسات آموزش گروهى مبتنى بر نظريه اميد اسنايدر (..... (Y) در جدول آمده است.

\footnotetext{
${ }^{1}$ - Magyar-Moe \& Jeana-L
}

كمتر مطالعهاى مبنى بر اثربخشى مداخلات آموزشى و

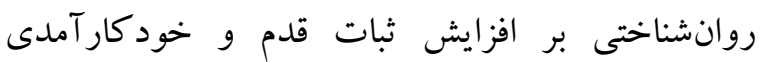
تحصيلى دانش آموزان كه به طور مستقيم هماهنگك با يثزوهش حاضر باشد، يافت شد. يُزوهشگران به جهت جديد بودن تركيب متغيرها و مداخله آموزشى سعى در انجام جنين يُوهشى نمودند؛ لذا اين مطالعه با هدف بررسى اثربخشى آموزش كروهى مبتنى بر نظريه اميد

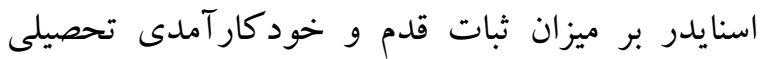

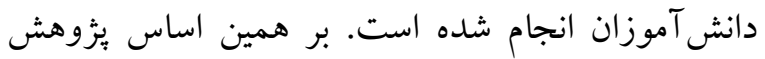
حاضر در بيى بررسى فرضيه هاى زير است: ا- آموزش كروهى مبتنى بر نظريه اميد اسنايدر موجب افز ايش ميز ان ثبات قدم دانش آموزان مى شود. Y- آموزش كروهى مبتى بر نظريه اميد اسنايدر موجب افزايش ميزان خود كار آمدى تحصيلى دانش آموزان مى شود. طرح كلى بثروهش حاضر با توجه به اهداف و ماهيت آن، آزمايشى با بيش آزمون- يس آزمون با كروه كنترل بود.

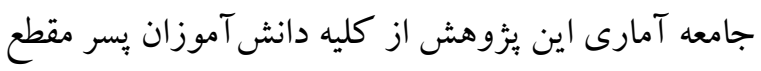
ابتدايى مشغول به تحصيل در سال تحصيلى IM-9VI در مدارس دولتى ناحيه ب شهر كرمانشاه تشكيل شده بود. حجم نمونه بر اساس نوع يزوهش كه در تحقيقات

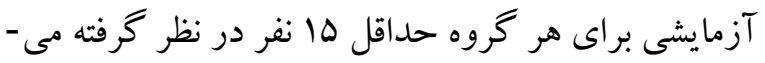

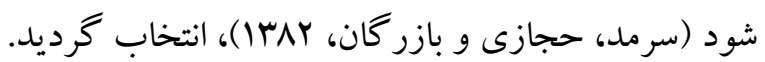
نمونه آمارى در يثزوهش حاضر ·ـ نفر از دانش آموزان يسر بِيه ششم بود كه براى انتخاب نمونه از روش نمونه كيرى خوشهاى تصادفى استفاده شد. گروهها قبل از اجراى آموزش از نظر هوش، بايه تحصيلى (ششم

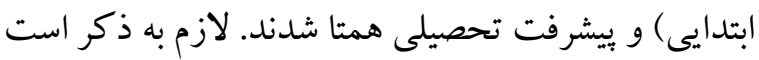
براى همتاسازى دانش آموزان از نظر هوش و ويشرفت 


\section{جدول ا خلاصه جلسات آموزش تروهى مبتنى بر نظريه اميد اسنايدر (·+...)}

\section{هدف و محتوا}

جلسه

معارفه و آشنايى يُروهش با دانش آموزان به عنوان اعضاى كلاس آموزشى، آشنايى با قوانين جلسات و ساختار گروه، ايجاد انخيزه و اجراى

بيش آزمون

بيان اهداف تشكيل و بر گزارى جلسات آموزشى و ارائه مفاهيم پايه در نظريه اميد اسنايدر

دوم

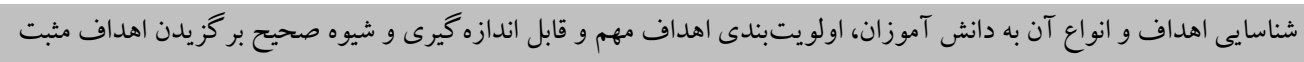

سوم

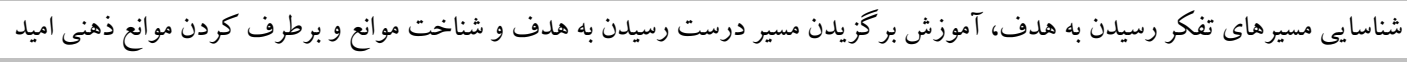

جهارم

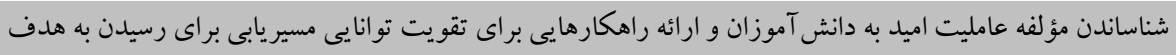

קنجمم

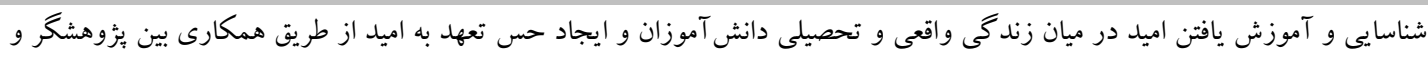

ششم

دانش آموزان

بالا بردن تفكر اميدوار در دانش آموزان، آموزش جكونخى خود بازنخرى بر تفكرات اميدوار و آموزش استفاده از تكنيكهاى افزايش اميد به

هفتم

دانش آموز

هشتم جمعبندى جلسات آموزشى و نتيجه گيرى كلى از جلسات و اجراى يس آزمون

كوشش "را مورد تأييد قرار داد و در نهايت تعداد گويهها

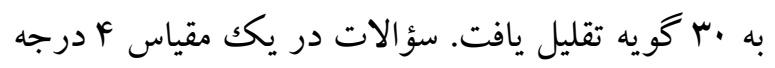

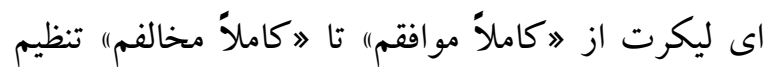
شدهاند. بالاترين نمره • با امتياز است كه نشاندهنده

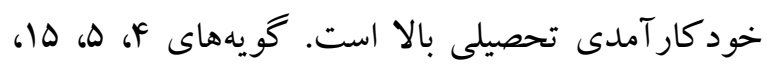

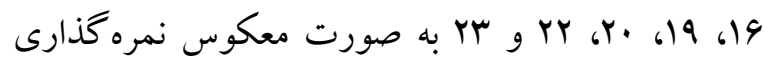
مىشوند. موركان و جينكز (199V) با استفاده از آلفاى كرونباخ يايايى اين آزمون را براى كل مقياس و هريك از خرده مقياسهاى استعداد، بافت و كوشش به ترتيب

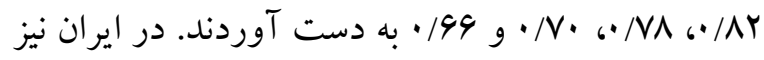
جمالى، نوروزى و طهماسبى (rar) ضريب آلفاى كرونباخ را براى خود كار آمدى كلى V9/•، خرده مقياس

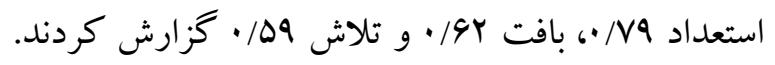

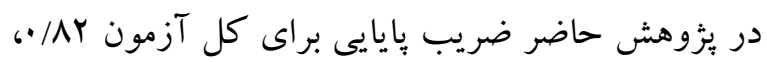
عامل استعداد NV/ •، عامل بافت 191/، و عامل كوشش 19V • به دست آمد.

4- Effort
پِ از اجراى برنامه آموزشى، بـ آزمون اجرا گرديد و نتايج استخراج و ثبت شد و سبس دادههاى جمع آورى -

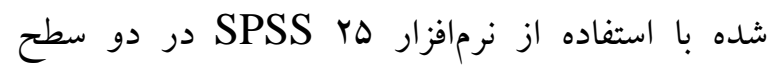

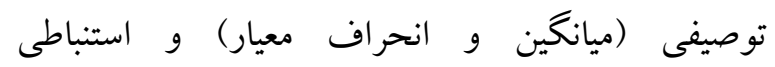
(كواريانس جند متغيره) مورد تجزيه و تحليل آمارى قرار كرفتند.

ابز ار در اين بزوهش براى جمع آورى اطلاعات از ابزارهاى زير استفاده شد:

مقياس خودكارآملى تحصيلى جينكز و موركان (MJSES) 1991 طراحى شد. فرم اوليه آن داراى سه گويه بود كه به منظور بررسى اعتبار عاملى اين مقياس از تحليل عاملى

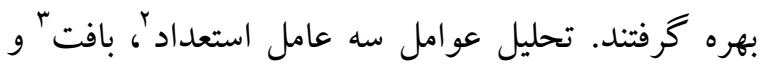

\footnotetext{
1 -Morgan \& Jinks academic Self-Efficacy Scale

2 -Talent

3 - Context
} 
آزمونهاى بارامتريكك مورد سنجش قرار گرفت. بر همين

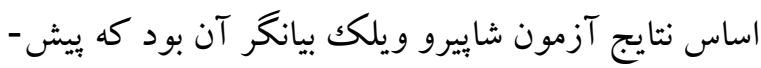
فرض نرمال بودن توزيع نمونهاى دادهها برقرار است

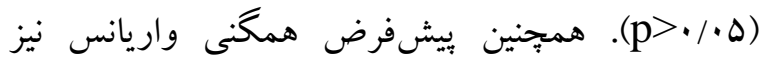
توسط آزمون لوين مورد سنجش قرار گرفت كه نتايج آن

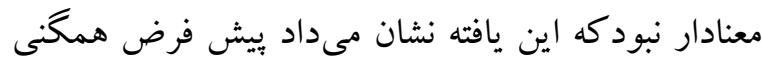

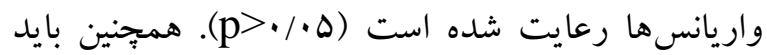
اشاره كرد كه در بررسى بيشفرض همخنى شيب خط رگرسيون، نتايج نشان داد كه تعامل بيش آزمون با متغير كروهبندى در مراحل بس آزمون در متغيرهاى ثابتقدم و خود كار آمدى تحصيلى معنادار نبوده است. اين بدان معناست كه فرض همگنى شيب خط رگرسيون در

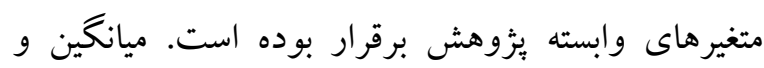
انحر اف معيار متغيرهاى ثبات قدم و خود كار آمدى در دو كروه آزمايش و كنترل در موقعيت بيش آزمون و بس آزمون در جدول r آمده است.
يرسشنامه ثبات قدم داكورث (DGS)'؛ اين برسشنامه در سال Y...V توسط آنجلا داكورث ساخته شده است و داراى rا گويه و دو بعد ثبات در علاقهَ و يشتكار در

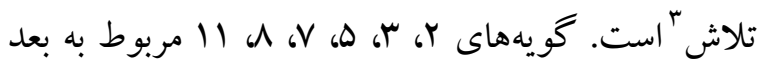
ثبات در علاقه و 1، F، 9، 9، · ل و و ا مربوط به بعد يشتكار در تلاش است. گويههاى اين برسشنامه با روش

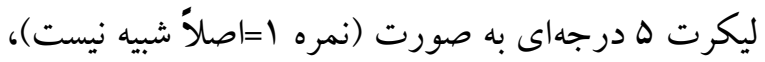
(نمره Y= خيلى شبيه نيست)، (نمره بr= گاهى شبيه است)، (نمره F= خيلى شبيه است) و (نمره ه= كاملاً شبيه است)

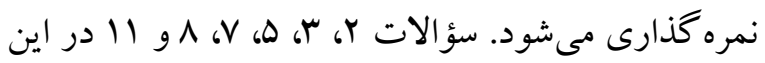
برسشنامه به صورت معكوس نمره كذارى مى شوند. دامنه نمره كلى اين برسشنامه از با تا •و است و نمرات بالا در اين برسشنامه نشان دهنده ثبات قدم بيشتر در فرد است.

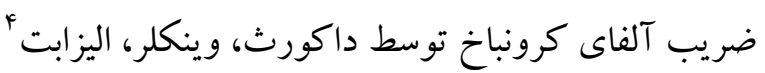

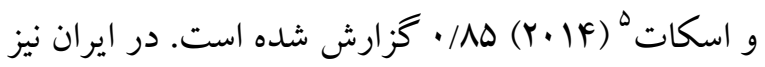
يايايى اين برسشنامه با استفاده از ضريب آلفاى كرونباخ

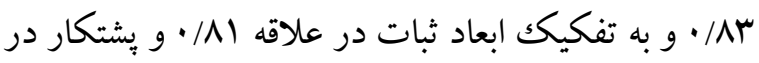
تلاش •^/ · به دست آمده است (حسينى، ذوقى پايدار و رشيد، IM IVI). در بزوهش حاضر ضريب آلفاى كرونباخ

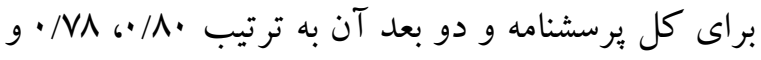
/VD

\section{يافته ها}

در اين بُزوهش ·r دانش آموز يايه ششم شركت داشتند كه آزمودنى ها در گرووه آزمايش و كنترل داراى ميانخين

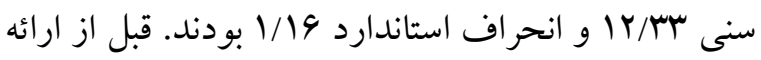

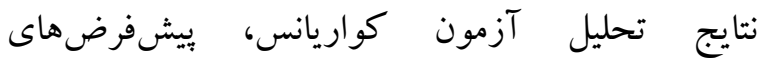

1 - Duckworth Grit Scale (DGS)

${ }^{2}$ - Stability in interest

${ }^{3}$ - Perseverance in effort

${ }^{4}$ - Elizabeth

5 - Scott 
جدول r ميانكين و انحر اف معيار نمرات مربوط به متغير هاى ثبات قدم و خود كار آمدى تحصيلى

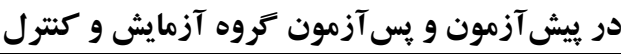

\begin{tabular}{|c|c|c|c|c|c|}
\hline \multicolumn{2}{|c|}{ يس آزمون } & \multicolumn{2}{|c|}{ ييش آزمون } & \multirow[t]{2}{*}{ متغير } & \multirow[t]{2}{*}{ كروه } \\
\hline انحراف معيار & ميانكين & انحراف معيار & ميانكين & & \\
\hline $4 / 11$ & 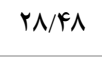 & $r / \cdot r$ & $r / \Delta$. & 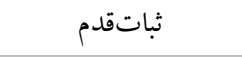 & كروه آزمايش \\
\hline$৭ / \wedge \Delta$ & $99 / \%$. & $1 / 90$ & $\Delta \Lambda / 9 T$ & خود كار آمدى تحصيلى & \\
\hline$\Delta / Y q$ & rI/V. & $4 / \cdot q$ & $r Y / \cdot r$ & 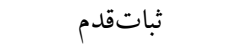 & كروه كنترل \\
\hline $9 / 01$ & 91 & $V / \cdot r$ & $\Delta 9 / \wedge 1$ & خود كار آمدى تحصيلى & \\
\hline
\end{tabular}

افزايش يافته است. نتايج تحليل كواريانس تأثير آموزش

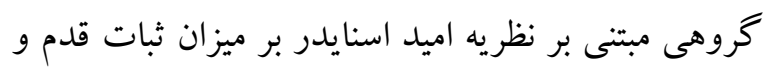

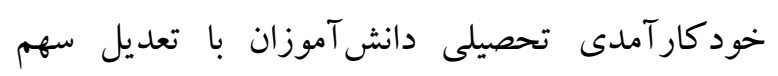
ييش آزمون در جدول ب آمده است.
نتايج حاصل از جدول r حاكى از آن است كه ميانكين

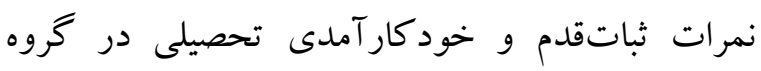
آزمايش در اثر آموزش گروهى مبتى بر نظريه اميد اسنايدر در مقايسه با گروه كنترل در مرحله يس آزمون

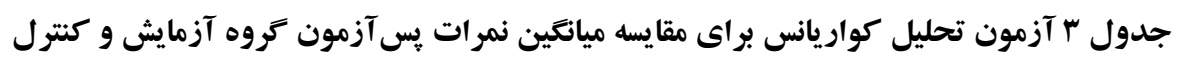

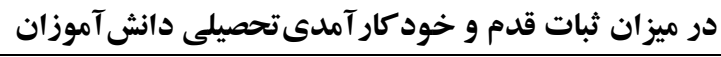

\begin{tabular}{|c|c|c|c|c|c|c|c|c|}
\hline آزمون & اندازه & معنادارى سطح & نسبت F & مجذوراتنين & آزادى درجه & مجذوروات & شاخصها & متغير ها \\
\hline$\cdot|r|$ &.$/ r$ &.$/ 49$ & $\cdot / 09$ & r/AY & 1 & r/Ar & ييش آزمون & \multirow{4}{*}{ ثبات قدم } \\
\hline 1 & $\cdot / 4 r$ & $\cdot / \cdots \cdot 1$ & $F V / \pi$ & rrg/Aq & 1 & rrq/99 & عضويت گروهى & \\
\hline & & & & $\Delta$ & 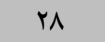 & $\mid r \Delta / r$. & خطا & \\
\hline & & & & & $r$. & indra & كل & \\
\hline$\cdot / A$ &.$/ . .1$ & - /AD &. & . & 1 & D & ييش آزمون & \multirow{4}{*}{ خود كار آمدى } \\
\hline \multirow[t]{3}{*}{1} & .109 &.$/ \cdots \cdot 1$ & $r \mid \& \Delta$ & rar/4G & 1 & MaY/AD & عضويت گروهى & \\
\hline & & & & $11 / 90$ & rA & $r_{1 . / .1}$ & خطا & \\
\hline & & & & & r. & ITr.FV & كل & \\
\hline
\end{tabular}

نمرات متغيرهاى ثبات قدم و خود كار آمدى تحصيلى با آموزش گروهى مبتنى بر نظريه اميد اسنايدر تغيير يافته است. اين بدان معناست كه به ترتيب سج و وهه درصد

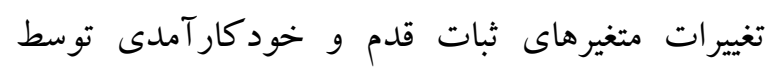
عضويت گروهى (آموزش مبتنى بر نظريه اميد اسنايدر) تبيين مىشود. بحث همان گونه كه در جدول r ملاحظه مىشود، ميزان تأثير براى ثبات قدم سَ//· و براى خود كارآمدى تحصيلى

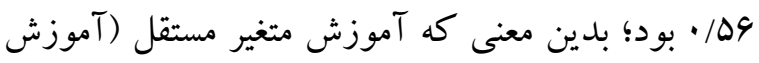

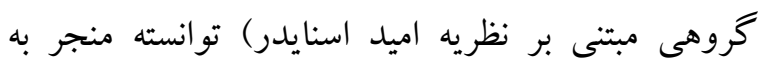
ايجاد تفاوت معنادار ميانگين نمرات متغيرهاى وابسته (ثبات قدم و خود كارآمدى تحصيلى) در مرحله

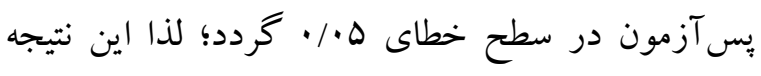
حاصل مىشود كه با كنترل متغيرهاى مداخله كر، ميانكين 


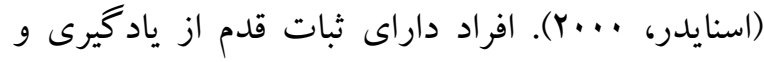
انجام تكاليف لذت برده، در انجام كارهاى فكرى استقامت بالايى داشته و ساعات طولانىترى روى تكاليف كار مى كنند، اين افراد اهداف و معيارهاى دقيقى براى خود وضع مى كنند و در برابر شكستها تسليم نمىشوند و با اميد به فعاليت خود تا زمان رسيدن به هدف ادامه مى دهند (حسينى و همكاران، لو I I). در تبيين اين يافته مى توان بيان داشت كه اميدوارى با افزايش سطح اشتياق و علاقه، منجر به افزايش ثبات قدم براى رسيدن به هدفهاى از ييش تعيين شده، تعهد و يشتكار در فرد مىشود. نتايج حاصل از اين يزوهش در مورد تأثير آموزش اميد بر افزايش خود كار آمدى دانش آموزان با نتايج يزوهش -

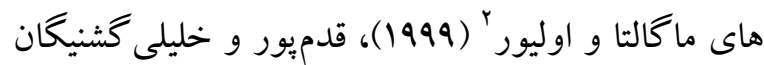

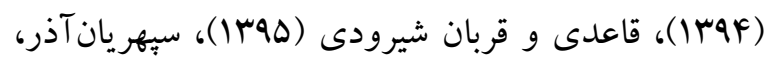
محمدى آذر و موهنا (هوسا) همخوان است. ابراهيمى، صباغيان و ابوالقاسمى ( •وسا) در پيخوهشى نشان دادند كه بين دو عامل اميد و موفقيت تحصيلى رابطه معنادار وجود دارد. افرادى كه از ظرفيت اميدوارى بالاترى برخوردارند، توانايى زيادى در تنظيم اهداف تسلطى و افزايش يادگيرى دارند، اين افراد به منظور دستيابى به هدفهاى خود تلاش زيادى مى كنند و در صورت مواجهه با موانع، توانايى بالايى در يافتن مسيرهاى

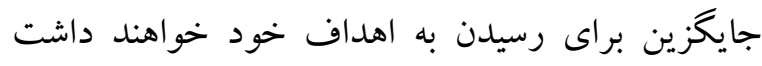

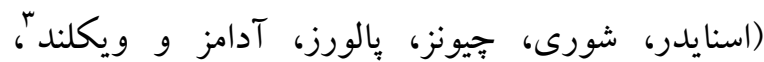

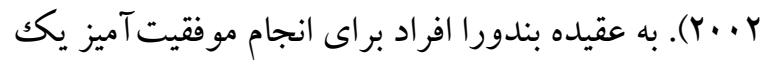
تكليف نه تنها به مهارت و دانش نياز دارند، بلكه بايد قبل از انجام تكليف، سطح مشخصى از انتظارات و معيارها را براى موفقيت داشته باشند كه ميزان برآورده شدن اين
يثزوهش كنونى به منظور بررسى اثربخشى آموزش كروهى مبتنى بر نظريه اميد اسنايدر بر ميزان ثبات قدم و برو

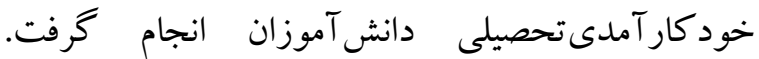
يافتهاى به دست آمده از تحليل دادهها نشان داد كه آموزش گروهى مبتنى بر نظريه اميد اسنايدر بر ميزان ثباتقدم و خود كار آمدى تحصيلى د دانشآموزان مؤثر بوده است. بدين معنا كه اين آموزش موجب افزايش ثبات قدم و خود كار آمدىتحصيلى دانش آموزان شده

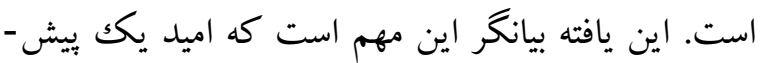
بينى كننده و يكك عامل مؤثر براى افزايش ثبات قدم و خود كار آمدى تحصيلى در دانش آموزان است؛ به عبارتى، هراندازه فرد از اميدوارى بالاترى برخوردار باشد، با احتمال بيشترى ثبات قدم و خود كارآمدىتحصيلى بيشترى را تجربه مى كند. به بيان ديخر، هرجه فرد داراى سطح بالاترى از اميد باشد، سطح بالاترى از موفقيت و بيشرفت تحصيلى خواهد داشت. نتايج بزوهش حاضر مبنى بر اثربخشى آموزش گروهى

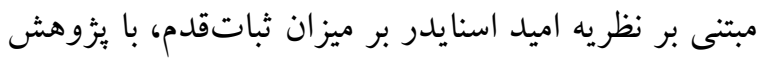

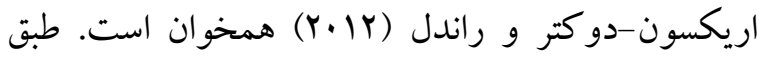
نظر داكورث، ثبات قدم نوعى خودتنظيمى است كه

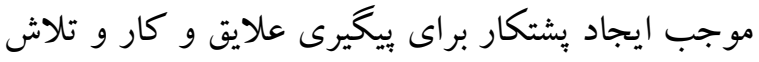
مداوم براى دستيابى به اهداف بلندمدت مىشود و فرد علىرغم و جود مشكلات، ناميدىها، شكست ها و تغييرها در طول مسير، با حفظ بشتكار و توجه به هدف، موانع و جالشها را با موفقيت يشت سر مى كذارد (داكورث،

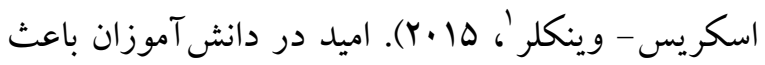
مىشود اين افراد به اهداف خود اطمينان داشته و مسير موفقيت را با ثبات و ايستادكى و بدون خستخى طى كنند 
اثربخشى آموزش گروهى اميد بر ثبات قدم و

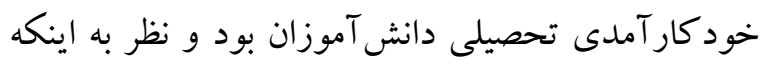
ثبات قدم، خود كار آمدى و مؤلفههاى آن قابليت آموزش دارند و همجنين به علت اهميت خودكار آمدى در

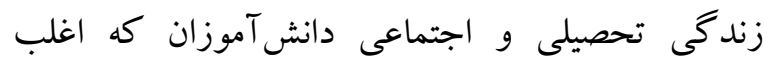

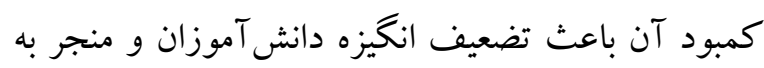
بسيارى از مشكلات افت تحصيلى و مشكلات روحى از

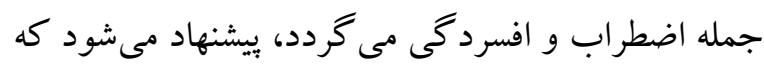

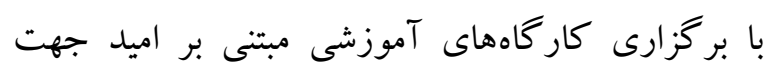

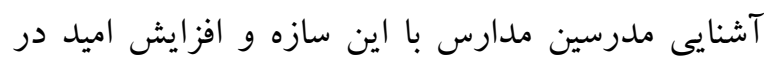
دانش آموزان، تدابير آموزشى و مديريتى توسط مسئولين

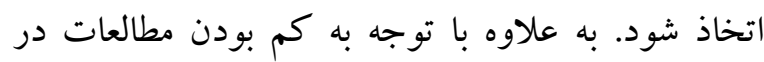

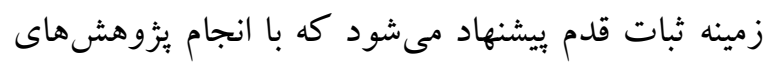
بيشتر در اين زمينه و اثربخشى آموزش اميد بر روى نمونهاى متفاوت ييشينه غنى ترى فراهم گرد درد.

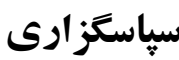

در بايان از همه شركت كند كان يُروهش حاضر و تمامى

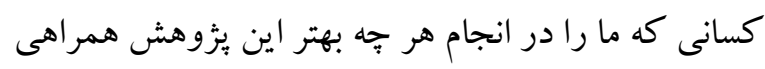

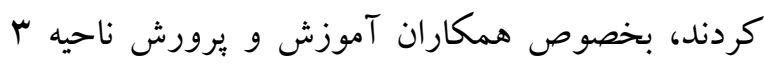
شهر كرمانشاه، كمال تشكر و قدردانى راد داريم.

\section{References}

Altunsoy S, Çimen O, Ekici G, Atik AD, \& Gökmen A. (2010). An assessment of the factors that influence biology teacher candidates' levels of academic self-efficacy. Procedia-Social and Behavioral Sciences, 2(2), 2377-2382.

Amini R, Sadeghi A. (2016). The effect of leaming success intelligence on well-being and academic self-efficacy in female students. Journal of education, counseling and psychotherapy, 5(18), 107-94.(In persian).
معيارها، احساس خود كار آمدى را تعيين مى كند (بيرامى، هاشمى، عبداللهى عدلى انصار و علائى، •وسا). به طورى كه در همين راستا مطالعات مربوط به خود كار آمدى نشان مىدهد كه باورهاى دانش آموزان در مورد ظرفيتشان با موفقيت در مدرسه مرتبط است (سبهريانآذر، محمودى،

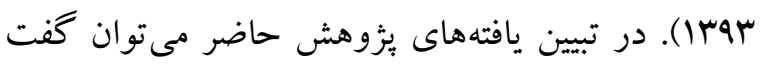

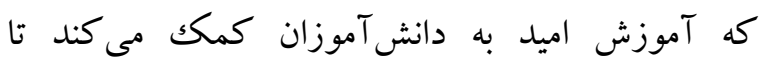
كذر گاههاى مختلف به سمت هدف را تعيين كرده و انكيزه خود را براى حركت در اين مسيرها حفظ و با هاب موانع بيشرو مقابله نمايد؛ زيرا دانش آموزان اميدوار براى رسيدن به هدف و در برابر موانع تحصيلى استقامت بيشترى نشان مىدهند و آينده روشنى را بيشروى خود

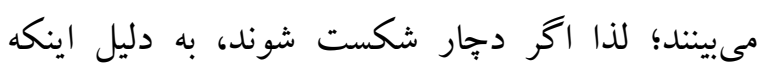
تو انايىهاى خود را باور دارند تلاش بيشترى مى كنند.

\section{نتيجه كيرى}

طبق يافتهاى بيزوهش حاضر مىتوان اميد را به عنوان

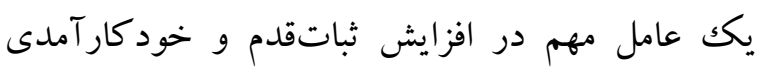
تحصيلى دانشآموزان در نظر كرفت؛ بدين معنى كه با بـ بـ تقويت حس اميدوارى مىتوان به افزايش خود كار آمدى و ثبات قدم در دانش آموزان كمكك كرد كه اين خود منجر به موفقيت و كار آمدى بيشتر در تحصيل دانش آموز

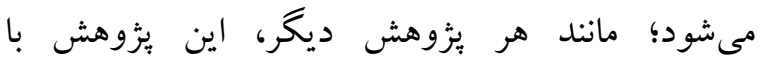
محدوديتهايى نظير محدوديت منطقه جغرافيايى (شهر كرمانشاه)، جامعه آمارى (دانش آموزان مقطع ابتدايى) و نيز عدم بركزارى مرحله بيخيرى مواجه بود؛ بنابراين ييشنهاد مىشود يزوهش كنونى با جامعه آمارى و محدوده جغر افيايى ديخر و بر خزارى مرحله بيخيرى انجام يافته تا روايى بيرونى نتايج بثوهش افزايش يابد. همجنين با توجه به نتايج يثوهش حاضر كه حاكى از قدرت 
Bandura A. (2001). Social cognitive theory: An agentic perspective. Annual Review of Psychology, 52(1), 1-26.

Bayrami M, Hashemi T, Abdollahi Adly Ansar V, \& Alaei P. (2011). Prediction of leaming strategies, self-efficacy and academic achievement based on the progress of the second year students of tabriz city, islamic azad univesity of education, 1(7), 86-65. (In persian).

Berk RA. (2018). Grit 2.0: A Review with Strategies to Deal with Disappointment, Rejection, and Failure. The Joumal of Faculty Development, 32(2), 91-104.

Cross TM, Arizona Ph. (2013). The Gritty: Grit and Non-traditional Doctoral Student Success, Grand Canyon University USA.

Duckworth AL, Eskreis-Winkler L. (2015). Grit. In J. D. Wright (Ed.), Intemational encyclopedia of the social and behavioral sciences, 2, 397-401. Oxford, UK: Elsevier.

Duckworth AL, Peterson C, Matthews MD, Kelly DR. (2007). "Grit: Perseverance and passion for long-term goals". Journal of Personality and Social Psychology, 92, 1087-1101.

Duckworth AL, Winkler LE, Elizabeth PB, Scott A. (2014). "The grit effect: predicting retention in the military, the workplace, school and marriage", Front Psychology, 5(36), 1-12.

Ebrahimi N, Sabaghian Z, \& Abolghasemi M. (2011). Investigating Relationship of Hope and Academic Success of College Students. IRPHE, 17 (2):1-16. (In persian).

Erickson-Dockter K, Randall B. (2012). Is it always good to persevere? Associations among hope, grit, \& cognitions that promote gambling. North Dakota.

Farrington CA, Roderick M, Allensworth E, Nagaoka J, Keyes TS, Johnson DW, \& Beechum NO. (2012). Teaching adolescents to become leamers. The role of noncognitive factors in shaping school performance: A critical literature review. Chicago, IL: University of chicago consortium on chicago school research.
Galyon CE, Blondin CA, Yaw JS, Nalls ML, Williams RL. (2012). The relationship of academic selfefficacy to class participation and exam performance. Social Psychology of Education, 15(2), 233-249.

Ghadampour E, Khalili E, Geshniani Z (2015). Relationship in Hope and academic motivation with academic self-efficacy in high school students. International Conference on Management and Social Sciences. (In persian).

Ghaedi Taher M, Ghorban Shiroodi S. (2013). The efficacy of group hope Therapy on depression, loneliness, and self-efficacy in female students. JCMH, 3 (2),65-75. (In persian).

Gurses A, Kaya O, Dogar Ç, Gunes K, Yolcu HH. (2010). Measurement of secondary school students' test-anxiety levels and investigation of their causes. Journal of Social and Behavioral Sciences. 9: 1005-1008.

Hosseini M, Zoghi Paydar MR, Rashid Kh. (2018). The roles of grit and intelligence in predicting students' academic achievement. Biquarterly joumal of cognitive strategies in leaming, 6(11), 249-233. (In persian).

Ivcevic Z, Brackett M. (2014). "Predicting school success: Comparing Conscientiousness, Grit, and Emotion Regulation Ability", Joumal of Research in Personality, 52 (3), 29-36.

Jamali M, Nowroozi A, Tahmasebi R. (2013). Factors affecting academic self-efficacy and its relationship with academic success in students of bushehr university of medical sciences 2012-2013. Iranian Journal of Medical Education, 13(1), 641-629. (In persian).

Magaletta PR, Oliver JM. (1999). The hope construct, will, and ways: Their relations with selfefficacy, optimism, and general well-being. Journal Clinical Psychology. 55(5), 39-51.

Magyar-Moe \& Jeana-L. (2018). Positive psychology techniques (guide for therapists). Translation by Farid Barati sadeh, roshd publishing (original publication date: 2009). (In persian).

MikaeliManba F, Fathi G, Shohodi M, Zandi Kh. (2014). Analysis of relationships between hope, self-efficacy, motivation and stressors 
with academic compatibility among undergraduate students in Urmia. New Educational Thoughts, 11(1), 78-57. (In persian).

Morgan V, Jinks J. (1997). Children's perceived academic self-efficacy: An inventory scale. The Clearing House, 72(4), 224-230.

Nasas G. (2014). Academic self-efficacy: A reliable predictor of educational performance. British Journal of Education, 2(3), 57-64.

Peguero AA, \& Shaffer KA. (2015). Academic selfefficacy, dropping out, and the significance of inequality. Sociological Spectrum, 35(1), 4664.

Sarmad Z, Bazargan A, \& Hejazi E. (2009). Research method in behavioral sciences. Tehran: Agah Publication. (In persian).

Sepehrianazar F, Mahmoudi N. (2015). The Study of Prevalence of Bullying and Comparing the Academic Achievement, Social SelfEfficacy and General Health of Adolescents with Bully and Ordinary Behavior. Psychology Educational in Research Applied, 1, 2, 23-32. (In persian).

Sepehrianazar F, Mohammadiazar M, \& Mohanna S. (2016). Hope cognitive training Effect on Self efficacy in First grade high school female students. Journal of Psychology. 11(41), 7997. (In persian).

Snyder CR, Shorey HS, Cheavens J, Pulvers KM, Adams VH, \& Wiklund C. (2002). Hope and academic success in college. Joumal of Educational Psychology, 94, 820-826.

Snyder CR. (2000). Handbook of hope: Theory, measures, and applications. San Diego: Academic press.

Snyder CR. (2002). Hope Theory: Rainbows in the Mind, Psychological Inquiry, 13(4), 249-275.

Tschudy J. (2010). Finding, nurturing, and engendering hope in marriage and family therapy. Utah State University.

Yaqubi A, Forotan Bagha P, \& Mohagheghi H. (2014). Effectiveness of hope training on students styles. Journal of Clinical Psychology Studies, 17(5), 33-19. (In persian).
Zimmerman BJ, Bandura A, \& Martinz-Ponz M. (2007). Perception of afficacy and strasegy use in the self-regulation of learning. Causes and consequences, 8(4), 185-207. 